\title{
First Confirmed Occurrence of a Wolf, Canis lupus, South of the St. Lawrence River in Over 100 Years
}

\author{
MARio VILLEMURE ${ }^{1}$ and HÉLÈne JOLICOEUR ${ }^{2}$ \\ ${ }^{1}$ Université de Sherbrooke, Département de Biologie, Sherbrooke, Québec J1K 2R1 Canada Current address: 11A, chemin \\ St-François, St-Mathieu-du-Parc, Québec GOX 1N0 Canada \\ ${ }^{2}$ Société de la faune et des parcs du Québec, Direction du développement de la faune, 675, boulevard René-Lévesque Est. \\ $11^{\text {th }}$ floor, box 92, Québec, Québec G1R 5V7 Canada
}

Villemure, Mario, and Helene Jolicoeur. 2004. First confirmed occurrence of a Wolf, Canis lupus, south of the St. Lawrence River in over 100 years. Canadian Field-Naturalist 118(4): 608-610.

A large canid was snared near Sainte-Marguerite-de-Lingwick, Québec, in January 2002. DNA analysis confirmed the animal to be a Wolf (Canis lupus). Wolves were extirpated from this region around 1850-1900 and this is the first confirmed observation since then.

Key Words: Wolf, Canis lupus, range, dispersal, St. Lawrence River, Québec.

Historically, Wolves (Canis lupus) were distributed across most of North America. They were extirpated in the southern portion of their range by the turn of the century (Nowak 1983). In Québec, Wolves disappeared from the south shore of the St. Lawrence River around 1850-1900 (Peterson 1966). The extermination of the Wolf and the development of agriculture in the mid-1900 facilitated the extension of Coyote (Canis latrans) range. Wolves are now mostly limited to the northern and less populated regions of North America (Wayne et al. 1992).

On 19 January 2002, a male Wolf was trapped near the village of Sainte-Marguerite-de-Lingwick $\left(45^{\circ} 36^{\prime} 15^{\prime \prime} \mathrm{N}, 71^{\circ} 17^{\prime} 15^{\prime \prime} \mathrm{W}\right)$ in the Eastern Townships of southern Québec. The Wolf weighed $29.1 \mathrm{~kg}$, similar to the weight of an adult from Papineau-Labelle (Potvin 1986*) or a yearling from the Laurentides region (Jolicoeur 1998*). A tissue sample was collected from the temporal muscle for genetic identification of the species. DNA analyses were performed by the Natural Resources DNA Profiling and Forensic Center (Trent University, Peterborough, Ontario K9J 7B8 Canada) following the method described in Wilson et al. (2000). The Eastern Townships sample was profiled at the mitochondrial DNA (mtDNA) control region and 8 microsatellite loci. The genetic profile was compared to samples of canids representing the Eastern Wolf $(C$. lupus lycaon) from Algonquin Provincial Park; Western Coyotes (C. latrans) from Texas, North Carolina and Ohio; and Wolves (C. lupus) from Pukaskwa National Park, northeastern Ontario and the Laurentide Wildlife Reserve region north of Québec City. The above populations were used to compare the Eastern Townships sample against $C$. lupus lycaon, $C$. latrans and $C$. lupus to assess the species-of-origin or hybrid genotype.

The sample had a mtDNA consistent with C. l. lycaon/ C. latrans and the microsatellite genotype suggested 95.0\% shared ancestry with Eastern Wolves from Algonquin Provincial Park. The sample had a DNA profile consistent with an Eastern Wolf. The Eastern
Wolf is generally described as being smaller than other Gray Wolf subspecies (Nowak 1995, 2002). Although it has been proposed as a distinct species (C. lycaon) by Wilson et al. (2000), its status as a subspecies is still generally accepted. Some authors suggest it may result from hybridization between $C$. rufus and $C$. Iupus (Nowak 2002). In Québec, the Eastern Wolf is found mostly in the southern deciduous and mixed forests (Jolicoeur and Henault 2002*) Coyote genes found in the mitochondrial DNA of the specimen have been reported before in Wolves in eastern Canada (Lehman et al. 1991; Wilson et al. 2000). Wolves and Coyotes are most likely to interbreed when Wolf density is low relative to Coyotes and when the species are similar in size. In southern Québec, male Coyotes weigh 14.6-18.7 kg (Fortin and Huot 1995*; Dumond and Villard 2000; Villemure 2003*).

Wolf dispersal has been monitored in southern Québec (Messier 1985; Potvin 1987; Jolicoeur 1998*; Villemure 2003*, but Wolves have not been documented crossing the St. Lawrence River. Harrison and Chapin (1998) identified two potential corridors linking Wolf populations north of the St. Lawrence River to potential habitat in Maine and New Hampshire. However, movements of Wolves south of their current range are thought to be unlikely because of potential barriers such as the St. Lawrence Seaway and regions with high human population, high road density and intensive agriculture (Wydeven et al. 1998). Potential core habitat for Wolves has been identified in New England as well as the Eastern Townships and Beauce regions of Québec (Harrison and Chapin 1998; Mladenoff and Sickley 1998; Carroll 2003*; Jolicoeur and Etcheverry, in preparation*).

Wolves are highly mobile and frequently move over long distances (Van Camp and Glukie 1979; Fritts 1983; Mech 1987). Some of the longest dispersal movements documented (460-555 km) occurred across a mixture of forest, farmland, and 4-lane highways in the upper Midwest (Mech et al. 1995; Wydeven et al. 1995). A Wolf in Alberta crossed rivers $0.5-2.0 \mathrm{~km}$ 
wide during summer (Van Camp and Glukie 1979), and Wolves have crossed $24 \mathrm{~km}$ on a frozen lake (Mech 1966). Wolves have increased in Minnesota (Fuller et al. 1992), and since the mid-1970s have naturally recolonized portions of northern Wisconsin and, more recently, Upper Michigan (Mech and Nowak 1981; Fuller et al. 1992). Wolves from Canada have recolonized Montana for at least the past decade (Boyd et al. 1995). In a review of Wolf dispersal and recolonization, Wydeven et al. (1998) reported that 31 to $63 \%$ of dispersing Wolves successfully settled and formed pairs in new territories.

It is unclear whether Wolves have begun re-establishing in the Eastern Townships, or whether this Wolf was simply a dispersing individual. While the Eastern Townships may be a sink habitat for Wolves, this Wolf was caught only $30-50 \mathrm{~km}$ from potential Wolf habitat in Maine (Carroll 2003*). Further investigation is necessary to confirm other possible Wolf observations in these regions. Reporting of Wolf sightings or accidental Wolf captures south of the St Lawrence river should be encouraged.

\section{Acknowledgments}

We are grateful to Laurent Cloutier, trapper and former Eastern Townships Wildlife Protection Officer, for providing the specimen and details of the capture location. DNA analysis were funded by the Société de la Faune et des Parcs du Québec. Thanks to C. Carroll, M. Festa-Bianchet, C. Reining and P. Struhsacker for comments on an earlier draft of this manuscript.

\section{Documents Cited (marked * in text)}

Carrol, C. 2003. Carnivore restoration in the Northeastern U.S. and Southeastern Canada: a regional-scale analysis of habitat and population viability for wolf, lynx, and marten. Progress report 1: Wolf viability analysis. Prepared for The Wildlands Project. Orleans, California: Klamath Center for Conservation Research. 38 pages.

Fortin, C., and J. Huot. 1995. Écologie comparée du coyote, du lynx et du renard roux au pare national Forillon. Report prepared for Parks Canada. Département de Biologie, Universite Laval. Ste-Foy, Québec. 291 pages.

Jolicoeur, H. 1998. Le loup du massif du lac Jacques-Cartier. Québec, Ministère de l'Environnement et de la Faune, Direction de la Faune et des Habitats, Direction de la conservation et du patrimoine écologique. 132 pages.

Jolicoeur, H., and M. Hénault. 2002. Repartition géographique du loup et du coyote au sud du $52^{\mathrm{e}}$ parallèle et estimation de la population de loups du Québec. Québec, Societe de la faune et des pares du Québec, Direction du développement de la faune et Direction de l'aménagement de la faune des Laurentides. 51 pages.

Jolicoeur, H., and P. Etcheverry (in preparation). Habitat potentiel pour le loup sur la rive sud du St-Laurent. Québec, Sociète de la faune et des parcs du Québec, Direction du développement de la faune.

Potvin, F. 1986. Écologie du loup dans la reserve de Papineau-Labelle. Québec, Ministère du Loisir, de la Chasse et de la Pêche, Direction générale de la Faune. 103 pages.
Villemure, M. 2003. Écologie et conservation du loup dans la region du parc national de la Mauricie. Mémoire de Maîtrise. Département de Biologie, Universite de Sherbrooke. Sherbrooke, Québec, Canada. 89 pages.

\section{Literature Cited}

Boyd, D. K., P. C. Paquet, S. Donelon, R. R. Ream, D. H. Pletcher, and C. C. White. 1995. Transboundary movements of a recolonizing wolf population in the Rocky Mountains. Pages 141-146 in: Ecology and conservation of wolves in a changing world. Edited by L. N. Carbyn, S. H. Fritts and D. R. Seip. Canadian Circumpolar Institute, Occasional Publication Number 35, 642 pages.

Dumond, M., and M. A. Villard. 2000. Demography and body condition of coyotes (Canis latrans) in eastern New Brunswick. Canadian Journal of Zoology 78: 399-406.

Fritts, S. H. 1983. Record dispersal by a wolf from Minnesota. Journal of Mammalogy 64: 166-167.

Fuller, T. K, W. E. Berg, G. L. Radde, M. S. Lenarz, and G. Blair Joselyn. 1992. A history and current estimate of wolf distribution and numbers in Minnesota. Wildlife Society Bulletin 20: 42-55.

Harrison, D. J., and T. G. Chapin. 1998. Extent and connectivity of habitat for wolves in eastern North America. Wildlife Society Bulletin 26: 767-775.

Lehman, N., A. Eisenhawer, K. Hansen, L. D. Mech, R. O. Peterson, P. J. P. Gogan, and R. K. Wayne. 1991. Introgression of coyote mitochondrial DNA into sympatric North American gray wolf populations. Evolution 45: 104-119.

Mech, L. D. 1966. The wolves of Isle Royale. U.S. National Park Service, Fauna Series 7.

Mech, L. D. 1987. Age, season, distance, direction, and social aspects of wolf dispersal from a Minnesota pack. Pages 55-74 in Mammalian dispersal patterns: The effects of social structure on population genetics. Edited by B. D. Chepko-Sade and Z. Tang Halpin. University of Chicago Press. Chicago. 342 pages.

Mech, L. D., S. H. Fritts, and D. Wagner. 1995. Minnesota Wolf dispersal to Wisconsin and Michigan. American Midland Naturalist 133: 368-370.

Mech, L. D., and R. M. Nowak. 1981. Return of the gray wolf to Wisconsin. American Midland Naturalist 105: 408-409.

Messier, F. 1985. Solitary living and extraterritorial movements of wolves in relation to social status and prey abundance. Canadian Journal of Zoology 63: 239-245.

Mladenoff, D. J., and T. A. Sickley. 1998. Assessing potential gray wolf restoration in the northeastern United States - a spatial prediction of favorable habitat and potential population levels. Journal of Wildlife Management 62: $1-10$.

Nowak, R. M. 1983. A perspective on the taxonomy of wolves in North America. Pages 10-19 in: Wolves in Canada and Alaska: their status, biology, and management. Edited by L. N. Carbyn. Canadian Wildlife Service. 145 pages.

Nowak, R. M. 1995. Another look at wolf taxonomy. Pages 375-397 in: Ecology and conservation of wolves in a changing world. Edited by L. N. Carbyn, S. H. Fritts and D. R. Seip. Canadian Circumpolar Institute, Occasional Publication Number 35, 642 pages.

Nowak, R. M. 2002. The original status of wolves in eastern north america. Southeastern Naturalist 1: 95-130.

Peterson, R. L. 1966. The mammals of eastern Canada. Oxford University Press. Toronto. 465 pages. 
Potvin, F. 1987. Wolf movement and population dynamics in Papineau-Labelle reserve, Québec. Canadian Journal of Zoology 66: 1266-1273.

Van Camp, J., and R. Glukie. 1979. A record long distance move by a wolf (Canis lupus). Journal of Mammalogy 60: 236-237.

Wayne, R K., N. Lehman, M. W. Allard, and R. L. Honeycutt. 1992. Mitochondrial DNA variability of the gray wolf: Genetic consequences of population decline and habitat fragmentation. Conservation Biology 6: 559-569.

Wilson, P. J., S. Grewal, I. D. Lawford, J. N. M. Heal, A. G. Granacki, D. Pennock, J. B. Theberge, M. T. Theberge, D. R. Voigt, W. Waddell, R. E. Chambers, P. C. Paquet, G. Goulet, D. Cluff, and B. N. White. 2000. DNA profiles of the eastern Canadian wolf and the red wolf provide evidence for a common evolutionary history independent of the gray wolf. Canadian Journal of Zoology 78: 2156-2166.

Wydeven, A. P., T. K. Fuller, W. Weber, and K. Mac Donald. 1998. The potential for wolf recovery in the Northeastern United States via dispersal from Southeastern Canada. Wildlife Society Bulletin 26: 776-784.

Wydeven, A. P., R. N. Schultz, and R. P. Thiel. 1995. Monitoring of a recovering gray wolf population in Wisconsin. Pages 147-156 in: Ecology and conservation of wolves in a changing world. Edited by L. N. Carbyn, S. H. Fritts, and D. R. Seip. Canadian Circumpolar Institute, Occasional Publication Number 35. 642 pages.

Received 11 August 2003

Accepted 24 December 2004 